\title{
APOLIPOPROTEIN AI-CIII GENE POLYMORPHISMS IN A JAPANESE POPULATION
}

\author{
Mieko Onuki, ${ }^{1}$ Yukio Iwamura, ${ }^{2}$ S.E. Humphries, ${ }^{3}$ \\ Juichi SatoH ${ }^{1}$, Naoko Hattori, ${ }^{1}$ Kimiko Yamakawa, ${ }^{1}$ \\ Yasuko YamanouchI, ${ }^{1}$ Takaaki OKAFUII, ${ }^{1}$ \\ and Hideo HaMaGuCHI ${ }^{1}$ \\ ${ }^{1}$ Department of Human Genetics and ${ }^{2}$ Department of Microbiology, \\ Institute of Basic Medical Sciences, University of Tsukuba, \\ Niihari-gun, Ibaraki 305, Japan \\ ${ }^{3}$ Department of Biochemistry, St. Mary's Hospital Medical School, \\ London, England
}

\begin{abstract}
Summary Apolipoprotein (apo) CIII $S s t$-I genotypes and apo AI $M s p$-I genotypes were investigated in 82 unrelated healthy Japanese, using genomic hybridization analysis with a $2.2 \mathrm{~kb}$ fragment of the human apo AI gene. The frequencies of the $S 2$ and $M 2$ alleles were 0.34 and 0.40 , respectively, and much higher than those in Caucasians. The alleles identified by the apo CIII Sst-I and apo AI $M s p$-I polymorphisms were observed to be in linkage disequilibrium $(\Delta=0.206 \pm 0.012, \mathrm{p}<0.001)$. Three of the four possible haplotypes were identified: the frequencies of the haplotype were $S 1-M 1=0.604, S 2-M 2=0.341$, and $S 1-M 2=0.055$. The data indicate that Japanese are characterized by the common presence of the haplotype $S 2-M 2$ as compared with Caucasians and that the haplotypes identified by the apo CIII $S s t-$ I and apo AI $M s p-I$ polymorphisms are useful genetic markers for Japanese.
\end{abstract}

\section{INTRODUCTION}

Apolipoprotein (apo) AI is the major protein constituent of high-density lipoprotein (HDL) and apo CIII is a component of chylomicrons, very-low-density lipoproteins (VLDL) and HDL (Herbert et al., 1983). The human apo AI and apo CIII genes are tightly linked and form a gene complex together with the apo AIV gene on the long arm of the chromosome 11 (Karathanasis et al., 1983; Law et al.,

Received August 5, 1986; Accepted September 17, 1986.

Offprint request to: Hideo Hamaguchi, Institute of Basic Medical Sciences, University of Tsukuba, Ibaraki 305, Japan 
1984; Cheung et al., 1984; Karathanasis, 1985; Elshourbagy et al., 1986). Restriction fragment length polymorphisms related to the apo AI and apo CIII genes have been reported to be associated with coronary atherosclerosis in Caucasians (Ferns et al., 1985; Rees et al., 1985; Ferns and Galton, 1986; Ordovas et al., 1986; Buraczynska et al., 1986). An apo AI-CIII gene polymorphism associated with coronary atherosclerosis is likely to be a linkage marker for a deleterious atherogenic gene in the apo AI-CIII-AIV gene complex. For the study as to the putative atherogenic gene in the apo AI-CIII-AIV gene complex in Japanese, it is important to reveal the characteristics of the genotypes of the apo AI-CIII-AIV gene complex in healthy Japanese populations. In this study, apo CIII Sst-I genotypes and apo AI Msp-I genotypes were investigated in 82 unrelated healthy Japanese.

\section{MATERIALS AND METHODS}

Blood was collected from 82 healthy members of the university staffs and

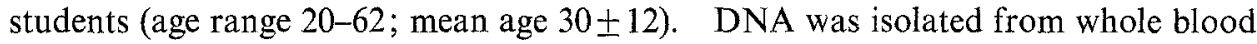
cells essentially according to the method of Kunkel et al. (1977). Ten $\mu \mathrm{g}$ DNA were digested with 60 units $S s t$-I or Msp-I using assay conditions specified by the manufacturers (Sst-I, BRL; Msp-I, Nippon Gene Co., Ltd., Toyama). Digests of DNA were electrophoresed on $1.0 \%$ or $0.85 \%$ agarose gels and transferred onto nitrocellulose filters by Southern blotting (Southern, 1975). The filters were prehybridized in $6 \times \mathrm{SSC} ; 100 \mu \mathrm{g} / \mathrm{ml}$ salmon sperm DNA; $10 \times$ Denhart's solution for $7 \mathrm{hr}$ at $68^{\circ} \mathrm{C}$. The filters were then hybridized with a ${ }^{32} \mathrm{P}$-labeled fragment of the human apo AI gene in $1 \mathrm{M} \mathrm{NaCl} ; 10 \mathrm{~mm}$ EDTA; $0.1 \% \mathrm{SDS} ; 200 \mu \mathrm{g} / \mathrm{ml}$ salmon sperm DNA; $50 \mathrm{~mm}$ Tris- $\mathrm{HCl}$ at $\mathrm{pH} 8.0 ; 10 \times$ Denhart's solution overnight at $68^{\circ} \mathrm{C}$. The probe used was a $2.2 \mathrm{~kb} P_{s t}-\mathrm{I}$ fragment containing the entire coding region plus introns of the apo AI gene (Kessling et al., 1985). The apo AI gene probe was labeled by "nick translation" with ${ }^{32 P}$-dCTP using a kit (Amersham Radiochemicals). The filters were washed in $0.1 \times \mathrm{SSC} ; 0.1 \% \mathrm{SDS}$ for $4 \mathrm{hr}$ at $68^{\circ} \mathrm{C}$ and exposed at $-70^{\circ} \mathrm{C}$ to Kodak XAR-5 film. Fragment sizes were determined by running HindIII digested lambda phage fragments with each batch of digests.

\section{RESULTS}

Figure 1 shows representative autoradiograms of the apo CIII Sst-I and apo AI $M s p$-I genotypes together with a simplified restriction site map of the apo AICIII genes. The $S 1$ and $S 2$ alleles of the apo CIII $S s t-I$ genotypes were characterized by the fragments of $4.5 \mathrm{~kb}$ and $3.2 \mathrm{~kb}$, respectively. For the apo AI Msp-I genotypes, the $M I$ allele was characterized by the 1.0 and $0.7 \mathrm{~kb}$ bands and the $M 2$ allele by the $1.7 \mathrm{~kb}$ band.

Table 1 presents the distribution and allele frequencies of the apo CIII Sst-I genotypes and apo AI $M s p$-I genotypes in 82 unrelated healthy Japanese. The 


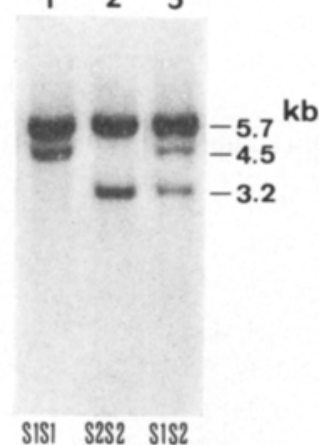

B 123

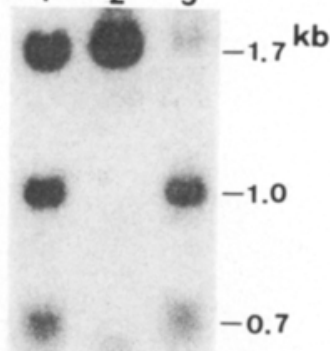

M1M2 M2N2 M1M1

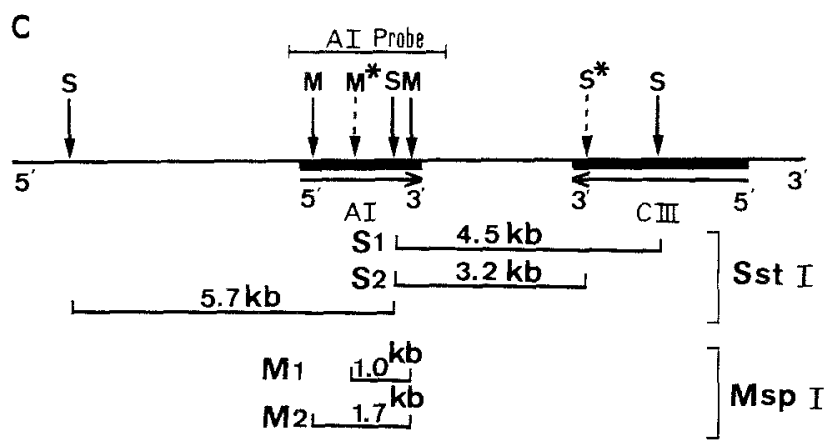

Fig. 1. Autoradiograms of apo CIII Sst-I genotypes (A) and apo AI $M s p$-I genotypes (B), and a simplified restriction site map of the apo AI-CIII genes (C). S* and $\mathrm{M}^{*}$ represent the polymorphic sites for the enzyme $S s t-\mathrm{I}$ and $M s p-\mathrm{I}$, respectively.

Table 1. Distribution and allele frequencies of the apo CII Sst-I genotypes and apo AI $M s p-I$ genotypes.

\begin{tabular}{|c|c|c|c|c|c|c|}
\hline \multirow[b]{2}{*}{ Apo CIII Sst-I } & \multirow[t]{2}{*}{$\mathrm{N}$} & \multicolumn{3}{|c|}{ Genotypes $(\%)$} & \multicolumn{2}{|c|}{ Allele } \\
\hline & & $S I S I$ & $S 1 S 2$ & $S 2 S 2$ & $S I$ & $S 2$ \\
\hline Observed & 82 & $37(45.1)$ & $34(41.5)$ & $11(13.4)$ & 0.66 & 0.34 \\
\hline Expected & 82 & 35.7 & 36.8 & 9.4 & & \\
\hline Apo AI $M s p *$ I & & $M 1 M I$ & $M 1 M 2$ & $M 2 M 2$ & $M I$ & $M 2$ \\
\hline Observed & 82 & $32(39.0)$ & $35(42.7)$ & $15(18.3)$ & 0.60 & 0.40 \\
\hline Expected & 82 & 29.5 & 39.4 & 13.1 & & \\
\hline
\end{tabular}

Expected values calculated from allele frequencies.

observed numbers are close to those calculated on the assumption that the HardyWeinberg equilibrium is observed (for the apo CIII $S s t$-I genotypes, $\chi^{2}=0.50$, d.f. $=$ $2,0.70<\mathrm{p}<0.75$; for the apo AI $M s p$-I genotypes, $\chi^{2}=0.96$, d.f. $=2,0.50<p<0.70$ ). 
Table 2. Observed and expected genotype frequencies assuming linkage disequilibrium or equilibrium.

\begin{tabular}{|c|c|c|c|c|c|}
\hline \multirow{2}{*}{ Genotype } & \multirow{2}{*}{$\begin{array}{l}\text { Observed } \\
\text { (N) }\end{array}$} & \multicolumn{4}{|c|}{ Expected } \\
\hline & & \multicolumn{2}{|c|}{ Disequilibrium $^{a}$} & \multicolumn{2}{|c|}{ Equilibrium ${ }^{b}$} \\
\hline$S I S I M I M 1$ & 32 & \multicolumn{2}{|l|}{29.9} & \multicolumn{2}{|l|}{14.4} \\
\hline$S 1 S 2 M 1 M 2$ & 30 & \multicolumn{2}{|l|}{33.8} & \multicolumn{2}{|l|}{14.5} \\
\hline$S 2 S 2 M 2 M 2$ & 11 & \multicolumn{2}{|l|}{9.6} & \multicolumn{2}{|l|}{2.0} \\
\hline$S I S 1 M I M 2$ & 5 & \multicolumn{2}{|l|}{5.4} & \multicolumn{2}{|l|}{15.8} \\
\hline$S 1 S 2 M 2 M 2$ & 4 & \multicolumn{2}{|c|}{3.1} & \multicolumn{2}{|l|}{6.2} \\
\hline$S 1 S I M 2 M 2$ & 0 & \multicolumn{2}{|l|}{0.2} & \multicolumn{2}{|l|}{6.8} \\
\hline$S I S 2 M 1 M I$ & 0 & 0 & \multirow[t]{3}{*}{3.3} & 13.3 & \multirow[t]{3}{*}{35.3} \\
\hline$S 2 S 2 M 1 M 1$ & 0 & 0 & & 4.3 & \\
\hline$S 2 S 2 M 1 M 2$ & 0 & 0 & & 4.7 & \\
\hline Total & 82 & \multicolumn{2}{|l|}{82} & \multicolumn{2}{|l|}{82} \\
\hline
\end{tabular}

a Expected values calculated from haplotype frequencies: $S 1-M 1=0.604, S 2-M 2=0.341, S 1-M 2=$ 0.055 . Expected values calculated from gene frequencies: $S I=0.66, S 2=0.34, M I=0.60, M 2=$ 0.40 .

Distribution of the combined $S_{s t}-\mathrm{J}$ and $M s p-\mathrm{I}$ genotypes are given in Table 2. Since none of the 82 subjects have the genotypes, SIS2MIMI,S2S2M1M2 and $S 2 S 2 M 1 M 1$, all the $S 2$ allele is considered to be associated with the $M 2$ allele at least in this population. As shown in Table 2, the distribution of the combined genotypes is compatibles with there being three of the four possible haplotypes: the frequencies of the haplotypes are $S 1-M 1=0.604, S 2-M 2=0.341$, and $S 1-M 2=$ $0.055\left(\chi^{2}=1.21\right.$, d.f. $\left.=4,0.80<\mathrm{p}<0.90\right)$. The linkage disequilibrium parameter $(A)$ calculated using the haplotype frequencies (Yasuda, 1978) is $0.206 \pm 0.012$ ( $\mathrm{p}<$ 0.001 ). In contrast, the distribution of the expected values assuming equilibrium between two polymorphic sites were highly significantly different from the observed $\left(\chi^{2}=129.7\right.$, d.f. $=4$ or $\chi^{2}=118.9$, d.f. $=8$ after Yates' correction; $\left.\mathrm{p}<0.001\right)$.

\section{DISCUSSION}

The apo CIII Sst-I polymorphism arises from a C-G transversion in the $3^{\prime}$ noncoding region of the apo CIII gene (Karathanasis et al., 1983). The apo AI Msp-1 polymorphism arises from the presence or absence of a $M s p$-I site in the third intron of the apo AI gene (Seilhamer et al., 1984). Several researchers have investigated the frequencies of the alleles of the apo CIIJ $S_{s t-I}$ genotypes or the apo AI $M s p-I$ genotypes, or both in healthy Caucasians but only 35 healthy Japanese were analyzed for the genotypes before this study (Rees et al., 1985; Kessling et al., 1985; Vella et al., 1985; Ferns and Galton, 1986; Deeb et al., 1986; Acton et al., 1986; Rees et al., 1986). A summary of their data is presented in Table 3 together with our 
Table 3. Summary of the frequencies of the alleles and haplotypes of the apo CIII Sist-I and apo AI Msp-I genotypes in healthy subjects obtained in previous studies.

\begin{tabular}{|c|c|c|c|c|c|c|c|c|}
\hline & \multirow{2}{*}{$\mathbf{N}$} & \multicolumn{4}{|c|}{ Alleles } & \multicolumn{3}{|c|}{ Haplotypes } \\
\hline & & $S 1$ & $S 2$ & $M I$ & $M 2$ & $S 1 M I$ & $S 1 M 2$ & $S 2 M 2$ \\
\hline \multicolumn{9}{|l|}{ Caucasins } \\
\hline Rees et al. (1985) & 52 & 1.00 & 0.00 & & & & & \\
\hline Kessling et al. (1985) & 77 & 0.94 & 0.06 & & & & & \\
\hline Vella et al. (1985) & 81 & 0.96 & 0.04 & & & & & \\
\hline Ferns and Galton (1985) & 48 & 0.99 & $0.01^{\mathrm{a}}$ & 0.94 & $0.06^{\mathrm{a}}$ & 0.94 & 0.05 & 0.01 \\
\hline Deeb et al. (1986) & 101 & 0.94 & 0.06 & & & & & \\
\hline Acton et al. (1986) & 53 & 0.95 & 0.05 & & & & & \\
\hline \multicolumn{9}{|l|}{ Japanese } \\
\hline Rees et al. (1986) & 35 & 0.61 & 0.39 & 0.56 & 0.44 & 0.56 & 0.057 & 0.39 \\
\hline This study & 82 & 0.66 & 0.34 & 0.60 & 0.40 & 0.60 & 0.055 & 0.34 \\
\hline
\end{tabular}

data. Both the $S 2$ and $M 2$ alleles are uncommon in healthy Caucasians and the $S 2$ allele has been reported to be associated with coronary atherosclerosis at least in local Caucasian populations (Ferns et al., 1985; Rees et al., 1985; Ferns and Galton, 1986; Deeb et al., 1986; Acton et al., 1986). The results of the present study indicate that both the $S 2$ and $M 2$ alleles are common in healthy Japanese. The frequencies of the $S 2$ and $M 2$ alleles observed in this study are similar to those for 35 healthy Japanese reported by Rees et al. (1986) as shown in Table 3. There were no differences in both the frequencies of the $S 2$ and $M 2$ alleles between Japanese myocardial infarction survivors and healthy subjects (Satoh et al., 1987).

The presence of linkage disequilibrium between the $S 2$ and $M 2$ alleles has been reported in both the Caucasians and Japanese (Ferns and Galton, 1986; Rees et al., 1986). In this study, it was clearly demonstrated that the allele identified by the apo CIII $S s t$-I and apo AI $M s p$-I polymorphisms are in linkage disequilibrium in Japanese $(A=0.206 \pm 0.012, p<0.001)$. Three of the four possible haplotypes were identified: the haplotype frequencies were $S I-M I=0.604, S 2-M 2=0.341$ and $S I$ $M 2=0.055$. The haplotype frequencies are similar to those for 35 healthy Japanese reported by Rees et al. (1986) as given in Table 3. Japanese are characterized by the common presence of the haplotype $S 2-M 2$ (Table 3). The heterozygosity of the haplotypes calculated from the result of this study is 0.52 . Therefore the haplotypes identified by the apo CIII $S s t-$ I and apo AI $M s p$-I polymorphisms are useful genetic markers for Japanese. Indeed the haplotypes have been effectively used for the genetic analysis of hypertriglyceridemia and myocardial infarction in Japanese (Rees et al., 1986; Satoh et al., 1987). 
Acknowledgments This study was supported by a Scientific Research Grant from the Ministry of Education, Science and Culture, No. 61571088, and a Research Grant for Intractable Diseases fom the Ministry of Health and Welfare, Japan. We are grateful to Miss N. Morohashi, University of Tsukuba for the preparation of the manuscript and to Mr. S. Abe, Mr. M. Teranishi and Mr. N. Shirato, University of Tsukuba for the preparation of the photograph.

\section{REFERENCES}

Acton, R., Vanichanan, C., Olson, G., Chandler, G., Barger, B., Go, R., Roseman, J., and Copeland, R. 1986. Immunogenetic and AI/CIII polymorphisms are risk factors for early onset coronary heart disease. Abstracts of the 7th International Congress of Human Genetics 750, West Berlin.

Buraczynska, M., Hanzlik, J., and Grzywa, M. 1986. Apo A-I related DNA polymorphism in humans with coronary heart disease. Hum. Genet. 74: 165-167.

Cheung, P., Kao, F.L., Law, M.L., Jones, C., Puck, T.T., and Chan, L. 1984. Localization of the structural gene for human apolipoprotein A-I on the long arm of human chromosome 11. Proc. Natl. Acad. Sci. U.S.A. 81 : 508-511.

Deeb, S., Motulsky, A., Failor, A., Walker, D., Brunzell, J., and Albers, J. 1986. Molecular genetics of apolipoproteins and coronary heart disease. Proceedings of the 7 th International Congress of Human Genetics 747, West Berlin.

Elshourbagy, N.A., Walker, D.W., Boguski, M.S., Gordon, J.I., and Taylor, J.M. 1986. The nucleotide and derived amino acid sequence of human apolipoprotein A-IV MRNA and the close linkage of its gene to the genes of apolipoproteins A-I and C-III. J. Biol. Chem. 261: 1998-2002.

Ferns, G.A.A., Stocks, J., Ritchie, C., and Galton, D.J. 1985. Genetic polymorphisms of apolipoprotein C-III and insulin in survivors of myocardial infarction. Lancet II: $300-303$.

Ferns, G.A.A. and Galton, D.J. 1986. Haplotypes of the human apoprotein AI-CIII-AIV gene cluster in coronary atherosclerosis. Hum. Genet, 73: 245-249.

Herbert, P.N., Assman, G., Gotto, A.M., and Fredrickson, D.S. 1983. Familial lipoprotein deficiency: Abetalipoproteinemia, hypobetalipoproteinemia, and Tangier disease. In The Metabolic Basis of Inherited Disease, Stunbury, J.B., Wyngaarden, J.B., Fredrickson, D.S., Goldstein, J.L., and Brown, M.S., eds., McGraw-Hill, New York, pp. 589-621.

Karathanasis, S.K., McPherson, J., Zannis, V.I., and Breslow, I.L. 1983. Linkage of human apolipoproteins A-I and C-III genes. Nature 304: 371-373.

Karathanasis, S.K. 1985. Apolipoprotein multiple gene family: Tandem organization of human apolipoprotein A-I, C-III, and A-IV genes. Proc. Natl. Acad. Sci. U.S.A. 82: 6374-6378.

Kessling, A.M., Horsthemke, B., and Humphries, S.E. 1985. A study of DNA polymorphisms around AI gene in hyperlipidaemia and normal individuals. Clin. Genet. 28: 296-306.

Kunkell, L.M., Smith, K.D., Bother, S.H., Borgaonkar, D.S., Wachtel, S.S., Miller, O.J., Breg, W.R., Jones, H.W., and Rary, J.M. 1977. Analysis of human Y-chromosome-specific reiterated DNA in chromosome variant. Proc. Natl. Acad. Sci. U.S.A. 74: 1245-1249.

Law, S.W., Gray, G., Brewer, H.B., Jr., Sakaguchi, A.Y., and Naylar, S.L. 1984. Human apolipoprotein A-I and C-III genes reside in the $\mathrm{P} 11 \rightarrow \mathrm{p} 13$ region of chromosome 11 . Biochem. Biophys. Res. Commun. 118: 934-942.

Ordovas, J.M., Ernst, J.E., Salem. D., Ward, R.H., Glueck, C.J., Vergani, C., Wilson, P.W.F., and Karathanasis, S.K. 1986. Apolipoprotein A-I gene polymorphism associated with premature coronary artery disease and familial hypoalphalipoproteinemia. N. Engl. J. Med. 314: 671-677.

Rees, A., Caplin, J.L., Jowett, N.I., Stocks, J., Williams, L.G., and Galton, D.J. 1985. DNA polymorphisms in the apo C-III and insulin gene and atherosclerosis. Atherosclerosis 58: 269-275.

Rees, A., Stocks, J., Paul, H., Ohuchi, Y., and Galton, D.J. 1986. Haplotypes identified by DNA 
polymorphisms at the apolipoprotein A-I and C-III and hypertriglyceriaemia: A study in a Japanese population. Hum. Genet. 72: 168-171.

Satoh, J., Hattori, N., Onuki, M., Yamakawa, K., Fujiwara, H., Amamiya, H., Nagaoka, H., Sakuma, T., Yamanouchi, Y., Okafuji, T., Iwamura, Y., Tsuchiya, S., Fukutomi, H., Ohsuga, T., and Hamaguchi, H. 1987. Apolipoprotein AI-CIII gene polymorphisms in Japanese myocardial infarction survivors. $J_{p n}$. J. Human. Genet. 32: 15-20.

Seilhamer, J.J., Protter, A.A., Frossard, P., and Levy-Wilson, B. 1984. Isolation and DNA sequence of full-length cDNA and of the entire gene for human apolipoprotein A-I: Discovery of a new genetic polymorphism in the apo A-I gene. DNA 3: 309-317.

Southern, E.M. 1975. Detection of specific sequences among DNA fragments separated by gel electrophoresis. J. Mol. Biol. 98: 503-517.

Vella, M., Kessling, A., Jowett, N., Rees, A., Stocks, J., Wallis, S., and Galton, D.J. 1985. DNA polymorphisms flanking the apo A-I and insulin genes and type III hyperlipidaemia. Hum. Genet. 69: 275-276.

Yasuda, N. 1978. The sampling variance of the linkage disequilibrium parameter in multi-allele loci. Heredity 41: 155-163. 